\title{
IMPLEMENTATION OF ANTI-CRISES INVESTMENT STRATEGIES: MACHINE-BUILDING CASE
}

https://doi.org/10.23939/semi2019.03.016

(C) Blynda Y. O., Prokopyshyn-Rashkevych L. M., Demkiv Y. V., Wasilewski M., 2019

In this research paper authors investigate the important component of enterprise stable operating activity, namely the investment strategies elaboration. As the high level of company competitiveness turns to be the necessary precondition for its stable operating, the impact of investment decisions on company's competitiveness level is analyzed. The competitiveness of enterprises requires the organization to product such goods and services that will meet the changing consumer demand for quality and price, which in turn requires regular technical and technological upgrading. Thus an appropriate investment strategy is needed. Taking into account the dynamics of modern economic development, as well as the possibility and mobility of various financial and economic priorities for the analyzed enterprises, in the paper authors consider following variants of investment strategies: focusing on the dominant factor strategy, polyfactorial strategy and balancing strategy.

In accordance with the correlation-regression analysis key indicators of the impact on the bankruptcy prevention index for the analyzed machinery enterprises have been chosen. These are four core indicators: the coefficient of turnover rate of stocks, the coefficient of financial stability, the coefficient of personnel turnover and the coefficient of information protection. Changing conditions of modern enterprise development, as well as the possibility of rapid change of its economic priorities, determine the choice of one of mentioned above investment strategies, to combine these key indicators in an appropriate to environment conditions way.

In paper authors provided the analysis of each of the influence indicators (the coefficient of financial stability, the coefficient of turnover rate of stocks, the coefficient of personnel turnover, coefficient of information protection) on the activity of the selected enterprises for determining the best recommendations for choosing and implementing an investment strategy has been carried out.

The main result of conducted investigation is a recommendation model that defines the selection of certain investment strategy based on key indicators. Therefore, the strategy of focusing on the dominant factor is oriented on the coefficient of financial stability, the polyfactorial strategy focuses on the coefficient of financial stability (like the previous strategy) and the coefficient of turnover rate of stocks, and the balancing strategy, as mentioned above aims to balance all four selected indicators.

Key words: investment strategy, key indicators, bankruptcy prevention, machinebuilding enterprises.

Ю. О. Блинда, Л. М. Прокопишин-Рашкевич, Я. В. Демків, М. Васелевскі ${ }^{1}$ Національний університет "Львівська політехніка",

${ }^{1}$ Суспільна Академія наук, (м. Лодзь, Польща)

\section{РЕАЛІЗАЦІЯ АНТИКРИЗОВИХ ІНВЕСТИЦІЙНИХ СТРАТЕГІЙ У МАШИНОБУДУВАННІ}

(ㄱ Блинда Ю. О., Прокопишин-Рашкевич Л. М., Демків Я. В., Васелевскі М., 2019

У статті досліджено важливу складову забезпечення стабільної діяльності підприсмства, а саме розроблення інвестиційних стратегій. Проаналізовано вплив 
інвестиційних рішень на рівень конкурентоспроможності підприсмства. Зазначено, що конкурентоспроможність підприсмств вимагає регулярного технічного і технологічного переозбросння i вдалих інвестиційних стратегій. Враховуючи динаміку сучасного економічного розвитку, автори розглядають такі варіанти інвестиційних стратегій: орієнтація на стратегію домінантного фактора, поліфакторну стратегію і стратегію балансування.

Автори виокремили ключові показники, які впливають на індекс профілактики банкрутства. Наявність декількох ключових показників вимагає вибору інвестиційної стратегіï, здатної забезпечити їх оптимальне посднання. Результатом проведеного дослідження є модель, що визначає вибір певної інвестиційної стратегії відповідно до поточного стану зазначених ключових показників.

Ключові слова: інвестиційна стратегія, ключові показники, запобігання банкрутства, машинобудівні підприсмства.

\section{Statement of the problem}

Essential changes in the Ukrainian economy due to the actual political changes and the intensity of globalization have a negative impact on the management of individual economic entities, particular their financial and economic activities.

Enterprises that timely implement investment activities, take measures aimed at overcoming dangerous situations, achieve positive results, while ignoring such measures can lead not only to the crisis situation, but also to bankruptcy and liquidation. At the current pace of technical and economic progress and globalization the economy of investment entrepreneurship not only does not lose its importance, but become more and more relevant.

\section{Analysis of recent research and publications}

The issues of some investment strategies and their implementation are devoted to the research of such scientists as Beach S. L., Rose C. C., Gitsham, I. O. Blank and others [1-4]. In addition, I. O. Makarenko, S. A. Saazhiyenko, A. P. Naumenko, T. O. Gavrilko, N. R. Augustine, C. Fronz consider some significant features of anti-crisis management in the prevention of enterprises' bankruptcy [5-9]. However, there is no single approach to the determination of anti-crisis investment strategies or some basic indicators of enterprises' bankruptcy that should be taken into account in order to choose the most appropriate model of strategy.

\section{The formulation of objectives}

The aim of this research paper is to identify some features of anti-crises investment strategies and give some recommendations for their implementation by machine-building enterprises. In order to achieve the defined aim we set the following objectives: 1) to choose key indicators that need to be analyzed in the term of their influence on bankruptcy prevention; 2) to choose an investment strategy that can change and improve indicator values; 3 ) to develop some possible measures that will be required to implement investment strategies for "Lvivskyi lokomotyvoremontnyi zavod".

\section{Presentation of main materials}

The competitiveness of enterprises, as a prerequisite for successful stable activity, requires the organization to produce such goods and services that will meet the changing consumer demand, what requires regular technical and technological upgrade. Thus an appropriate investment strategy is needed.

In order to establish dependence between core indicators, able to effect enterprises stable activity, authors performed regression analysis. As the basis for the above-mentioned regression analysis two domestic machinery enterprises were chosen. These are: PJSC "Drohobytskyi mashynobudivnyi zavod" and JSC "Lvivskyi lokomotyvoremontnyi zavod".

As the results of conducted regression analysis, following indicators were selected: dependent variable $(Z)$ - the value of discriminant function according to the model of Matviychuk; independent variables $\alpha_{1}$ - the coefficient of turnover rate of stocks; $\alpha_{2}$ - the coefficient of financial stability; $\alpha_{3}-$ the coefficient of personnel turnover; $\alpha_{4}$ - the coefficient of information protection. 
The evaluation of the results of the conducted correlation-regression analysis confirmed that the key indicators of the impact on the bankruptcy prevention index for the analyzed enterprises are following: 1) the coefficient of turnover rate of stocks; 2) the coefficient of financial stability; 3) the coefficient of personnel turnover; 4) the coefficient of information protection. Several key indicators make it necessary to choose an investment strategy that can affect the change one indicator and improve several or all the rest of them. Taking into account the dynamics of modern economic development, as well as the mobility of various financial and economic priorities for the analyzed enterprises, the following variants of investment strategies are considered: focusing strategy on the dominant factor; polyfactorial strategy; balancing strategy.

Since the influence level of each indicator on the dependent variable was calculated using regression analysis, it can be argued that when the weight of one indicator is significantly different from all the others, then it is advisable to apply a focus strategy. If there are several indicators of great importance, it is more efficient to apply a polyfactorial investment strategy. It is expedient to use a balanced investment strategy when the influence of indicators varies greatly from each other, and also when there is a number of stakeholders with a significant impact on the activity of the enterprise.

Preliminary analysis shows that for the the PJSC "Drohobytskyi mashynobudivnyi zavod" the stock turnover rate is the dominant indicator. The dynamics of the change in this ratio (Fig. 1) is characterized by an increase in the cost of inventories from 12,998 th. UAH in 2007 to 15,736 th. UAH in 2016 and some fluctuations in $2011-2014$. However, the cost of sold products rapidly decreased from 14,128 th. UAH in 2007 to 9226 th. UAH in 2016 In 2010, 2013 and 2015 there was a significant drop in the cost of sold products by $55 \%, 42.58 \%$ and $35.63 \%$ respectively. Stocks structure analysis, shows that the largest part of them is finished goods, on average $-55,2 \%$ and $16,3 \%$ respectively. Such a high proportion of finished products in stock of the company means that there are problems with its implementation. Thus the fall in the cost is due to a decrease in production volumes, because of crisis phenomena inherent in the Ukrainian economy during 2013-2016 and general instability. From the data shown in the graph, it can be concluded that the turnover rate of the stocks at PJSC "Drohobytskyi mashynobudivnyi zavod" differs significantly from the indicator of JSC "Lvivskyi lokomotyvoremontnyi zavod" and is several times lower than the average in the industry.

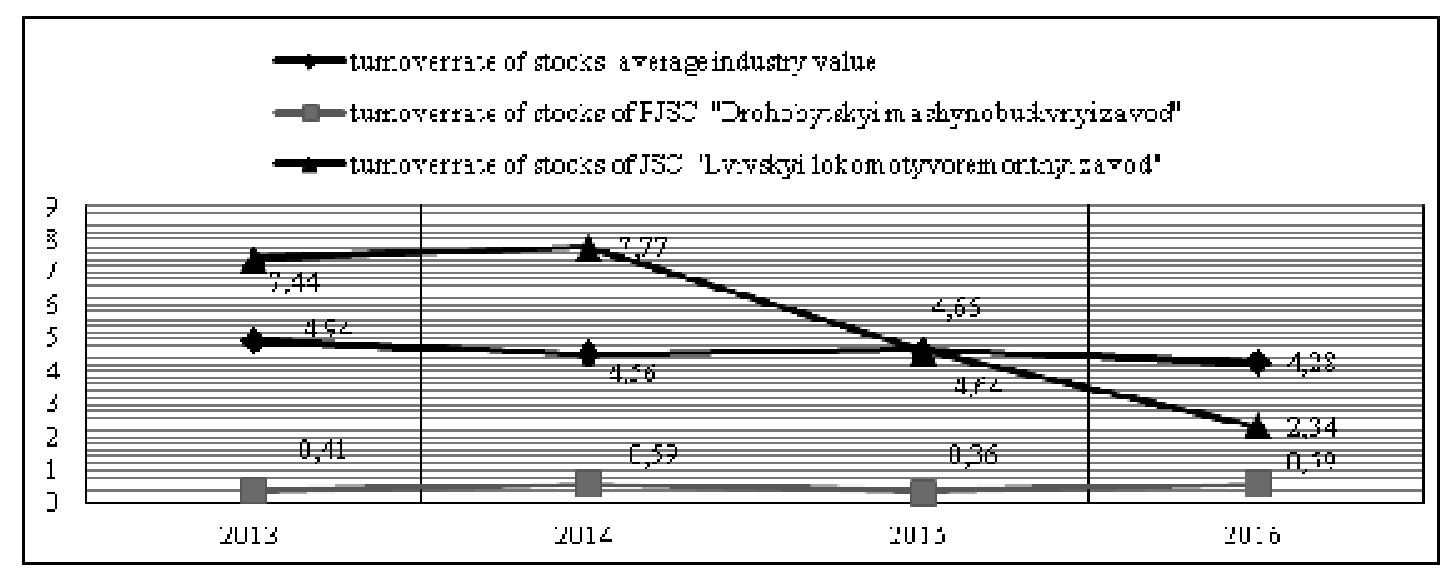

Fig. 1. Comparison of the turnover rate of stocks (unit share) JSC "Lvivskyi lokomotyvoremontnyi zavod" and PJSC "Drohobytskyi mashynobudivnyi zavod" with average industry value Note: developed by the authors on https://smida.gov.ua/ data basis

In the JSC "Lvivskyi lokomotyvoremontnyi zavod" the situation is slightly better. Turnover rate of stocks was 2.34 in 2006, but the dynamics of this indicator was disappointing, as in 2013, the it was 7.44. Particular attention should be paid to the stocks' value structure. In second case, we can outline that the finished goods share is only $3.82 \%$, unfinished construction $-40.42 \%$ and inventories $-55.75 \%$. As of the end of 2016, stocks and inventories grew by 6,825 th. UAH. (or $19 \%$ ), the value of unfinished construction - by 15,881 th. UAH (or $105 \%$ ), and the value of finished goods - by 2,393 th. UAH (or $448 \%$ ) compared to the beginning of the year. In the total amount of stocks at the end of 2016 (76607 th. 
UAH), the main share was made by unfinished construction (30 971 th. UAH or $40.4 \%$ ), semi-finished goods and component parts (23 218 th. UAH or $30.3 \%$ ).

Consequently, choosing the strategy of focusing on the turnover rate of stocks in order to reduce the risk of bankruptcy, PJSC "Drohobytskyi mashynobudivnyi zavod" should not only consider ways to increase the volume of sales of finished goods, but also to introduce modern inventory management systems. An overview of current practice and years of experience in implementing such systems has shown the feasibility of using two of them:

- the concept of "just in time", developed by Taiichi Ohno[10], which formed the basis for managing the production flow in the compilation of cars. Concept main objective is maximum integration of all logistics functions of the enterprise to minimize the level of material resources inventory in the integrated logistics system.

- MRP (Material Requirements Planning) - used when dealing with materials, components and semi-finished products, demand for which depends on the demand for specific finished products. J. Orlicky [11], the developer of this system, notes that the planning of need for materials in the narrow sense consists of a number of logically related procedures that define rules and requirements that transform the production plan into a chain of requirements synchronized in time and the planned "coatings" these requirements for each unit of inventory of components required to implement the production plan. The application of the MRP system involves a series of standard steps: the calculation of the net need for materials based on the data, composition and technological characteristics of the product; the amount of resources that need to be procured or developed to meet determined needs. This information is the basis for the respective activities of planning and supply departments.

Both of these inventory management systems were developed for foreign enterprises, but their essence and basic calculations were well-known in Ukrainian engineering. The reasons for their poor implementation are related to the remnants of centralized planning in industry, "bureaucratic machine" and other "atavisms" of socialist management methods.

Nevertheless, certain elements of these systems can be used now. For example, along with the automation of management procedures, it is expedient to implement electronic management of creating minimal inventories. The same approach also requires utilization of waste, as intensive production activity of the enterprises contributes to the accumulation of significant volumes of man-made waste, which affects the state of ecology, human health and labor activity negatively. Waste utilization methods of the machinebuilding complex depend on the type of waste. Among them, one can distinguish the following: 1) waste of galvanic production; 2) burning molding land; 3) scrap and waste of non-ferrous metals. Reducing the amount of finished goods inventories would release funds for investing.

According to the preliminary analysis, the financial stability of the enterprise is the dominant factor for JSC "Lvivskyi lokomotyvoremontnyi zavod". The index of financial stability is an indicator that characterizes the share in the total value of property that the enterprise can use in its current economic activity without prejudice to creditors. It is calculated as the ratio of equity to the borrowed.

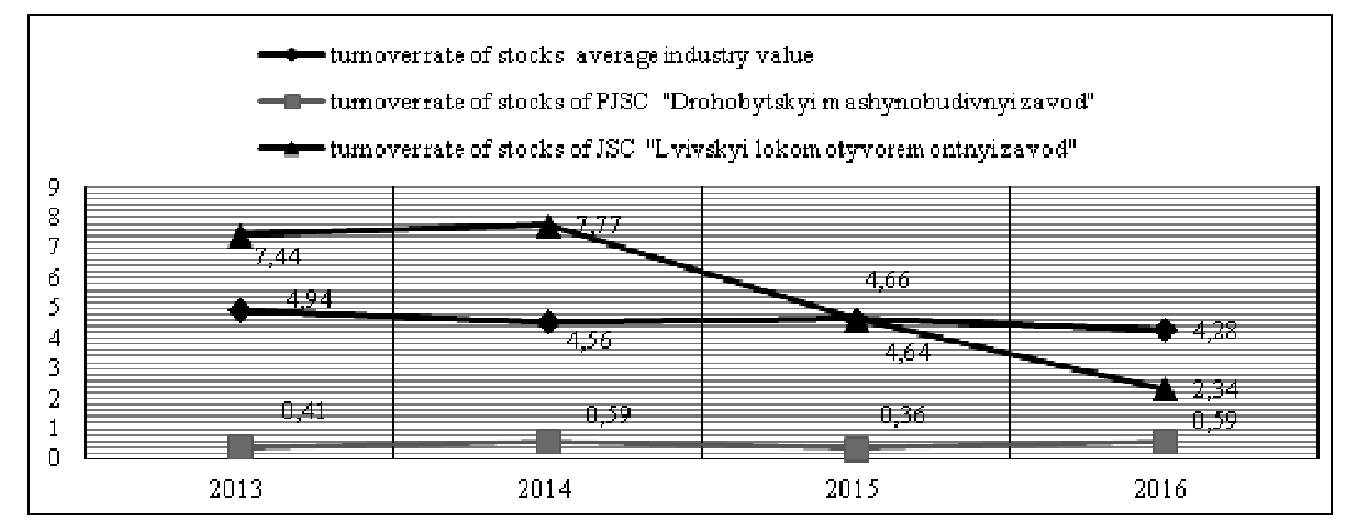

Fig. 2. Comparison of financial sustainability indexes of JSC "Lvivskyi lokomotyvoremontnyi zavod", PJSC "Drohobytskyi mashynobudivnyi zavod" and average value in the industry Note: developed by the authors on https://smida.gov.ual data basis 
Chart represents that the selected enterprises indexes of financial stability exceed the average indicators by industry. If in 2013 the deviation from the average industry index (0.613) for JSC "Lvivskyi lokomotyvoremontnyi zavod"(1.53) was up to $249.59 \%$, for PJSC "Drohobytskyi mashynobudivnyi zavod"(1.43) - 233.27\%. In 2016 the difference between average index (0.228) was $442.98 \%$ for JSC "Lvivskyi lokomotyvoremontnyi zavod"(1.01) and $328.94 \%$ for PJSC "Drohobytskyi mashynobudivnyi zavod"(0.75). As analyzed companies have a high probability of bankruptcy, they have difficulties with attracting capital from the outside.

For both companies, the size of this ratio is gradually decreasing. In PJSC "Drohobytskyi mashynobudivnyi zavod" from 2,1 in 2007 to 0,75 in 2016; in JSC "Lvivskyi lokomotyvoremontnyi zavod" from 3.34 in 2007 to 1.01 in 2016. This indicates an increase in the risk of successful enterprises activity and low ability to repay debt.

PJSC "Drohobytskyi mashynobudivnyi zavod" equity fell from 29470 th. UAH in 2007 to 21133 th. UAH in 2016. Instead, the attracted capital grew almost 2 times over the same period, from 14797 th. UAH up to 28160 th. UAH. The most rapid growth of attracted capital took place in 2010 and amounted to 46.61 $\%$ compare to last year. The JSC "Lvivskyi lokomotyvoremontnyi zavod" equity share shown growth since 2007 up to 2015 year, (from 110013 th. UAH to 163644 th. UAH). However, in 2016, this indicator dropped by $20.48 \%$ (33 414 th. UAH). Significant growth of attracted capital during the analyzed period (from 32944 th. UAH in 2007 to 128356 th. UAH in 2016) requires a special analysis: whether such growth can be estimated as a positive dynamics of financial stability, taking into account changes in other factors?

At the same time, the index of own capital growth $($ Ko.c $=0.80)$ is lower than the assets growth index $(\mathrm{Ka}=0,96)$. It leads to decrease of the enterprise activity own financing sources. The index of equity profitability, which represents the share of net profit in equity, gained a negative value $(-0.25)$ at an optimal value of $0.13-0.24$ in 2016. This indicates the low investment attractiveness of the enterprise. The aggregate capital profitability index, which shows the effectiveness of its use, also has a negative value $(-0.16)$ with an optimal $0.12-0.18$ in 2016 . This indicates that the enterprise activity is lossmaking.

The concentration of attracted capital ratio at the end of 2016 was 0.5 and is lower than the critical value $($ Ca.c = 1). The insufficient growth of this indicator in 2016 (0.39 in 2015), indicates a decrease in the stability of the business activity and independence from external creditors, which can affect the continuous functioning of the enterprise negatively.

Negative trend of financial stability can lead to enterprise functioning problems. An increase of one factor of this ratio influence will not be able to ensure the stable functioning of the enterprise. Therefore, it is proposed to increase both: own and attracted capital simultaneously. The increase of own capital can be achieved by increasing the share capital of JSC "Lvivskyi lokomotyvoremontnyi zavod". To achieve that, it is expedient to consider the following directions:

- holding an additional issue of shares since it is a private joint-stock company owned by PJSC "Ukrzaliznytsya", in which $100 \%$ of the shares of "Ukrzaliznytsia" are state-owned;

- develop a comprehensive program on the basis of the profitability analysis and diagnostics of the production capabilities;

- diversification of the nomenclature and restructuring of production in order to increase the net profit.

- To increase the attracted capital one should use the following:

- to assess the feasibility of attracting an external investor, including a foreign one, having analyzed the possibilities of state guarantees for such an investor;

- to consider options for restructuring existing loan debts and obtaining new loans from domestic or foreign lending institutions;

- to analyze existing state of business support programs and relevant international grants in order to take advantage of this support.

JSC "Lvivskyi lokomotyvoremontnyi zavod" as most domestic enterprises in the machine-building industry, uses obsolete equipment. The index of fixed assets depreciation (Figure 3) with a slight change in 2016 gained a high value ( $74 \%$ at the beginning of the year and $75 \%$ by the end of the year) and tends to 
increase. Indicating a gradual decrease in the moral and physical depreciation of fixed assets requires implementation of effective investment policy for the fixed assets renewal. The index of fixed assets refinancing amounted to only $0.7 \%$ at the end of 2016 at $1.5 \%$ at the beginning of the year. This indicates a negative trend in the cost of fixed assets due to their wear and tear renewal. Therefore, it is proposed to invest attracted funds into updating the company's fixed assets, which will allow to implement the program of production restructuring.

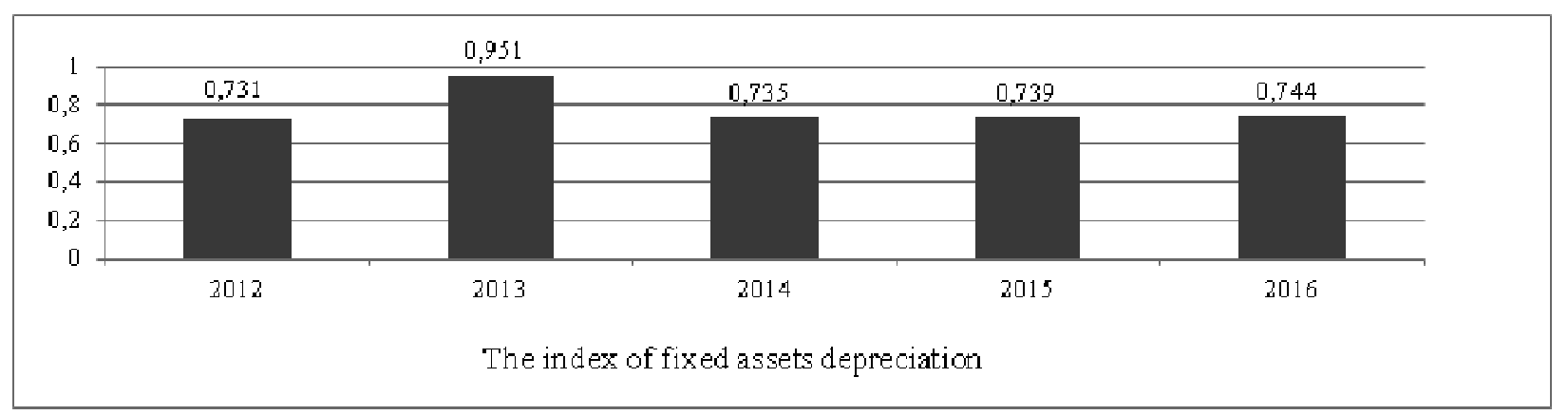

Fig. 3. Depreciation of fixed assets of JSC "Lvivskyi lokomotyvoremontnyi zavod" Note: developed by the authors on https://smida.gov.ual data basis

The prerequisite for the practical implementation the above listed measures: acceleration of the turnover of stocks (for PJSC "Drohobytskyi mashynobudivnyi zavod") and the increase of financial stability (for JSC "Lvivskyi lokomotyvoremontnyi zavod"), is carrying out large-scale audit activities, which require the involvement of a professional team of crisis managers, marketers, financiers and engineering specialists.

With all the expediency of focusing on the main problem, one must take into account that a modern market enterprise is an open complex system and its necessary to take into account a number of indicators. Therefore, the essence of the polyfactorial model lies in the investment strategy focus on several factors simultaneously. Obviously, this strategy will be more costly, but it is known from the scientific and practical experience that such an approach leads to the synergistic effect. That is, the initial cost of the strategy may coincide with or exceed the price of the previous option (focusing strategy), but due to synergy, the prospective effectiveness of the polyfactorial strategy may be significantly higher. Since every enterprise operates in a dynamic society, all existing indicator should be taken into account, even if their weight seems insignificant.

Thus, it can be argued that for the two companies, in case of choosing their polyfactor strategy, attention should be focused on the ratios of inventory turnover and financial stability. Such a strategy involves taking into account for each enterprise the two indicator factors described above, since according to the regression analysis they have the most significant impact on their activity.

The balancing strategy is based on the main aspects of stakeholder theory (interest groups). These include various groups of participants in economic processes, associated with the company. For the machine-building enterprises, the following main groups of stakeholders and their expectations can be distinguished:

- shareholders (owners) of the enterprise - access to the break-even point of enterprise, in further receiving profit (dividends);

- customers and consumers - availability and improving product quality, price stability;

- suppliers - uninterrupted sales of products, timely payment of their services;

- employees of the enterprise - the opportunity to receive wages in time - financial stability, in the long term - career growth;

- credit institutions - payment of debts on time and in appropriate volumes;

- state (state authorities) - payment of taxes, employment of the population.

All these expectations are different. To achieve them, companies need to come out of the crisis and become profitable. That is why it is proposed to use investment strategies for each enterprise. The 
balancing of such groups interests lies in organic unity, coherence, harmony and subordination. It determines the purposefulness of the economic behavior of the enterprise in the process of production, distribution, exchange and consumption of goods.

The aim of the balancing strategy is to achieve the harmonization of the groups' interests on the basis of ensuring their rights and meeting the priority needs with the indicators, which have the greatest impact on the financial and economic state of the enterprise. This strategy involves a set of measures to increase each of the indicators. In addition to the indicators described above and decisions aimed to improve them, according to this strategy it is necessary to take measures to increase such indicators as staff turnover index and information protection index.

Staff turnover index reflects the quantitative changes in the personnel of the enterprise and is calculated by the ratio of the dismissed workers (at their own will and for certain violations) to the average number of personnel. Normative value of the indicator is 3-5\%, so-called natural updating of the personnel. Analyzed enterprises have this indicator much higher: $21 \%$ in PJSC "Drohobytskyi mashynobudivnyi zavod" and $10 \%$ in JSC "Lvivskyi lokomotyvoremontnyi zavod". Such an excess of the norm occurs in connection with the constant reduction of employees. However, if we consider this indicator in terms of industry (in 2014 it was $29.19 \%$, in $2015-27.86 \%$, and in $2016-27.47 \%$ ), it comes to be lower than average [12].

Such level of staff turnover can be explained by unfavorable economic situation, low wages (Fig. 4) and unsatisfactory working conditions.

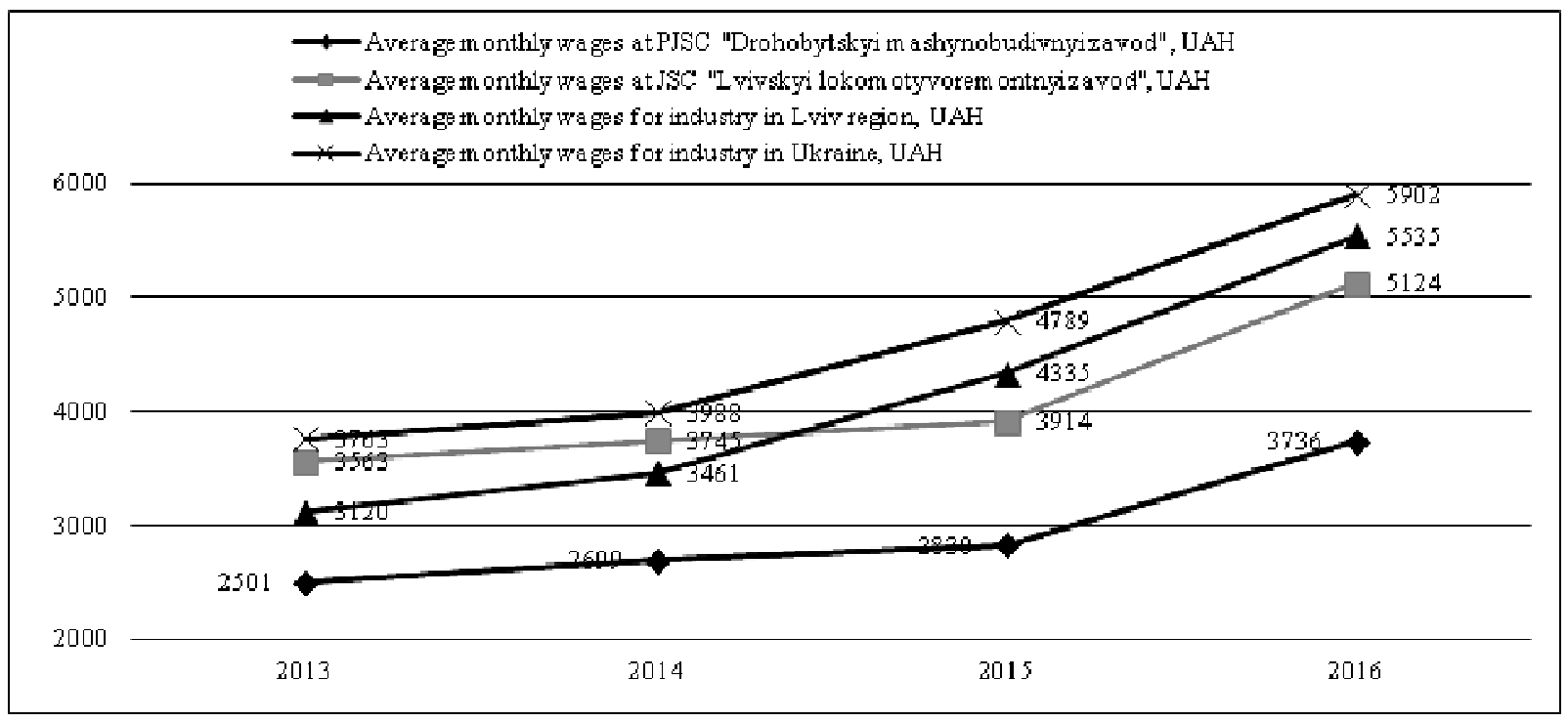

Fig. 4. Dynamics of wages in PJSC “Drohobytskyi mashynobudivnyi zavod”, JSC "Lvivskyi lokomotyvoremontnyi zavod”, average monthly salary for industry in Lviv region and industry in Ukraine Note: generated by the authors based on https://smida.gov.ua/ and http://www.ukrstat.gov.ua/ data

Therefore, in order to reduce the rate of staff turnover, it is necessary to raise the wage, as there is an outflow of highly skilled personnel in the neighboring EU countries due to changes in the legislation of these countries (an increase in the number of issued work permits for Ukrainian citizens). Another measure to reduce staff turnover is the introduction of a social package designed specifically for the needs of employees of these enterprises.

During the audit, it was established that at the JSC "Lvivskyi lokomotyvoremontnyi zavod" term for payment of wages was postponed in April, June, September, December 2016. According to the certificate provided by the enterprise, the payment of wages for four months was conducted with prolonged dates due to lack of funds on current accounts of the enterprise.

Due to the specifics of its activities, JSC "Lvivskyi lokomotyvoremontnyi zavod" is oriented on the execution of railway transport enterprises orders. This causes its dependence on the volume of orders and the timeliness of calculations of these enterprises for the performed work. In particular, PJSC 
"Ukrzaliznytsya" is the main customer of JSC "Lvivskyi lokomotyvoremontnyi zavod", which in accordance with Clauses 4, 30, 79 of the Articles of association of JSC "Lvivskyi lokomotyvoremontnyi zavod" in 2016, manages the corporate rights of the Company and is the sole shareholder of the Company [13]. Thus, in 2016 the Company produced commodity products in current prices for the total amount of 178465 th. UAH. At the same time from the total volume of commodity products for PJSC "Ukrzaliznytsya" and its affiliates, the Company produced products for 178051 th. UAH or $99.8 \%$ of the total volume. In general, the overly restrictive pricing policy of a monopoly-customer has a detrimental effect on production, due to lack of working capital, timely completion of production violation, deformed graphs of repair work, what leads to cost increase. In case of timely repayment of the receivables of PJSC "Ukrzaliznytsya" to JSC "Lvivskyi lokomotyvoremontnyi zavod", it would be possible to avoid delays in payment of wages.

PJSC "Drohobytskyi mashynobudivnyi zavod" has a similar situation with wages. Thus, according to the decision of the executive committee of the Drohobych City Council dated January 22, 2016, No. 7 "The implementation of the program of socio-economic and cultural development of the cities of Drohobych and Stebnyk for 2015" and the approval of the "Program of socio-economic and cultural development of the cities of Drohobych and Stebnyk in 2016 year" as of 01.01.2016, the payroll duty of PJSC "Drohobytskyi mashynobudivnyi zavod" amounted to 115.6 th. UAH. It should be noted that, as in the case of JSC "Lvivskyi lokomotyvoremontnyi zavod", PJSC "Drohobytskyi mashynobudivnyi zavod" has a sufficiently large receivables, 12885 th. UAH in 2015, and 12779 th. UAH in 2016, the repayment of which would allow to pay wages on time.

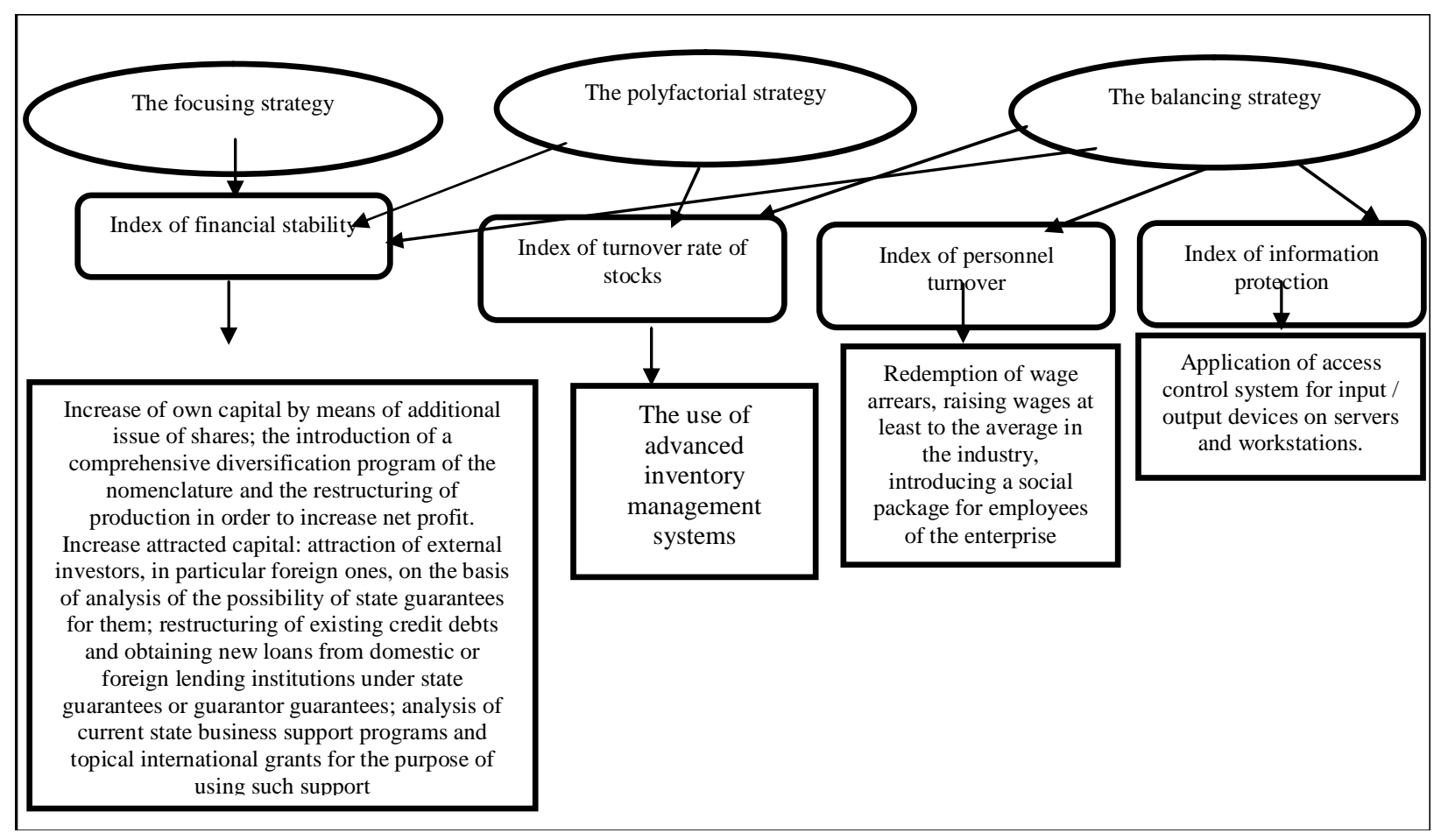

Fig. 5. Recommendation for selected investment strategies implementation Note: Elaborated by the authors

Information protection index characterizes the level of information security of the enterprise. The information space of the industrial enterprise receives data from both the external and the internal environment. Due to the information system, managers of industrial enterprises receive reliable measurements of the results of their managerial efforts to solve problems of adaptation to market requirements, financial management, personnel and other areas of activity. To make correct decisions on a modern enterprise, processing large amounts of information is required, and the terms and conditions of such processing are limited by time or other objective requirements. Therefore, the efficiency of 
management requires rational organization of information flows, unification and standardization of documents, and ensuring the protection of information from external interference. The diagnosis of information security of the analyzed enterprises was conducted in three key areas: assessment of software and technical security of information; assessment of information reliability of personnel; evaluation of information provided to decision makers. The generalized indicator was obtained by the expert estimation method. Normative value of the indicator:> 0.8 - reliable level; 0,5-0,8 - acceptable level; 0,3-0,5-critical level; <0.3 - critical (unsatisfactory) level. In 2016 PJSC "Drohobytskyi mashynobudivnyi zavod" represents this figure in accordance with- an acceptable level (0.56), while this indicator for JSC "Lvivskyi lokomotyvoremontnyi zavod" remained at the critical level $(0,38)$.

Fig. 5 shows the investment strategies proposed for JSC "Lvivskyi lokomotyvoremontnyi zavod" and possible measures that will be required to implement a strategy.

Proposed model was developed for JSC "Lvivskyi lokomotyvoremontnyi zavod", therefore, the strategy of focusing on the dominant factor is concentrated on index of financial stability, the polyfactorial strategy focuses on the index of financial stability (like the previous strategy) and the index of turnover rate of stocks, and the balancing strategy, as mentioned above aims to balance all four selected indicators.

\section{Conclusions}

Taking into account the dynamics of modern economic development, as well as the mobility of various financial and economic priorities for the analyzed enterprises, the following cases of investment strategies are considered: focusing strategy on the dominant factor; polyfactorial strategy; balancing strategy.

The analysis of some indicators (index of financial stability, index of turnover rate of stocks, index of personnel turnover, index of information protection) and their impact on the activity of the enterprises for determining the best recommendations for choosing and implementing an investment strategy has been carried out. Based on this analysis, measures are proposed to improve each indicator:

- index of financial stability: increase of own capital due to additional issue of shares; introduction of a comprehensive diversification program of the nomenclature and restructuring of production in order to increase net profit; increase of attracted capital: attraction of investors, including foreign ones, having analyzed the possibilities of state guarantees for such an investor; restructuring of existing loan debts and obtaining new loans from domestic or foreign lending institutions under state guarantees or guarantor guarantees; analyze existing state business support programs and leading international grants for the purpose of using such support;

- index of turnover rate of stocks: in addition to the computerization of management procedures, it is expedient to introduce electronic control of the creation of minimum stocks, first of all, in bottlenecks of production and economic activity to ensure the entire cycle, ranging from supply of resources and to the completion of production and the post of consumer guarantee services;

- index of personnel turnover: in order to reduce the turnover rate of personnel, it is necessary to raise the wage level first, as there is an outflow of highly skilled personnel in the neighboring EU countries due to changes in the legislation of these countries (an increase in the number of issued work permits for Ukrainian citizens) and according to the given statistical information the level of wages in the selected enterprises is lower than the average in industry in Ukraine in general and in the Lviv region in particular. Another measure to reduce staff turnover is the introduction of a social package designed specifically for the needs of employees of these enterprises;

- index of information protection: application of access control systems for input / output devices on servers and workstations; the introduction of biometric security systems to prevent the leakage of important information.

\section{Prospects for future research}

Future studies should be carried out to approbate some tools of core investment strategies by machine-building enterprises. More than that, it is worth doing some further research in order to identify some obstacles that can be occurred during the implementation of investment strategies and make reasonable decisions how to achieve appropriate results. 
1. Beach S. L., Rose C. C. (2008). Portfolio Rebalancing to Overcome Behavioral Mistakes in Investing. Journal of Behavioral Studies in Business. Available at: http://aabri.com/manuscripts/ 08055.pdf. 2. Gitsham A. (2011). Rebalancing to the Strategic Asset Allocation, Investment Analytics and Consulting by J. P. Morgan, March 2011 edition. Available at: http://www.jpmorgan.com/ cm/BlobServer/IAC_Q12011_Newsletter_PDF.pdf?blobkey=id\&blobnocache=true\&blobwhere $=1158625$ 602219\&blobheader=application\%2Fpdf\&blobcol=urldata\&blobtable=MungoBlobs.3. Бланк, И. А. (2009). Инвестиционный менеджмент.К.: Эльга-Н; Ника-Центр, 448 с. 4. Blynda, Yu. О., (2018). Phase, stage of crisis methods of reducing their dysfunctional consequences for enterprises. Економічний журнал Одеського політехнічного університету, 2 (4), 100-105. 5. Naumenko A. P., Gavrilko T. O. (2010). Antykryzove upravlinnia pidpryiemstvom, Available at: http:// www.nbuv/gov.ua/portal/soc_gum/ pei/2-10_25/naumenko.pdf [in Ukrainian]. 6. Sazhiyenko, S. A. (2009). The Role of anticrisis management in the prevention of bankruptcy of enterprises. Bulletin of Khmelnitsky National University, Available at: http://jounals.khnu.km.ua/vestnic/pdf/ekon/209_6_2/pdf/052-055.pf [in Ukrainian]. 7. Makarenko, I. O. (2005). The Algoritm of the enterprise crisis management, Actual problems of economy, 3, 104-109. 8. Augustine N. R. (1995) Managing the Crisis You Tried to Prevent. Harvard Business Review, 73(6). 147-158. 9. Fronz, C. (2011) Strategic Management in Crisis Communication: A Multinational Approach. Hamburg, Diplomica Verlag GmbH, 175 p. 10. Taiichi Ohno, (1988). Toyota Production System: Beyond Large-Scale Production. CRC Press, 176 p. 11. Orlicky J., (1975). Material Requirements Planning: The New Way of Life in Production and Inventory Management. NewYork: McGrow-Hill, 292 p. 12. Державна служба статистики України, Статистичний збірник "Регіони України", Available at: http://www.ukrstat.gov.ua/ 13. Державна аудиторська служба України, (2017) Аудиторський звіт за результатами державного фінансового аудиту діяльності ПрАТ “Львівський локомотиворемонтний завод”. Available at: http://dkrs.kmu.gov.ua/kru/doccatalog/document? id=131706

1. Beach S. L., Rose C.C. (2008). Portfolio Rebalancing to Overcome Behavioral Mistakes in Investing. Journal of Behavioral Studies in Business. Retrieved from: http://aabri.com/ manuscripts/08055.pdf. 2. Gitsham A. (2011). Rebalancing to the Strategic Asset Allocation, Investment Analytics and Consulting by J.P. Morgan, March 2011 edition. Retrieved from: http://www.jpmorgan. com/cm/BlobServer/IAC_Q12011_Newsletter_PDF.pdf?blobkey=id\&blobnocache=true\&blobwhere $=115$ 8625602219\&blobheader=application\%2Fpdf\&blobcol=urldata\&blobtable=MungoBlobs.3. Blank I. A. (2009). Investment Management. C .: Elga-N; Nick Center, 448 p. 4. Blynda, Yu. O., (2018). Phase, stage of crisis methods of reducing their dysfunctional consequences for enterprises. Economic Journal of the Odessa Polytechnic University, 2 (4), c. 100-105.5.Naumenko, A.P., Gavrilko, T.O. (2010). Antykryzove upravlinnia pidpryiemstvom [Anticrisis enterprise management] Retrieved from http:// www.nbuv/gov.ua/portal/soc_gum/pei/2-10_25/naumenko.pdf [in Ukrainian]. 6. Sazhiyenko, S. A. (2009). Rol antykryzovogo upravlinnia $\mathrm{v}$ zapobihanni bankrutstva pidpryimstv [The Role of anticrisis management in the prevention of bankruptcy of enterprises]. Visnyk Khmelnytskogo natsionalnoho universytetu Bulletin of Khmelnitsky National University, Retrieved from http://jounals.khnu.km.ua/vestnic/ pdf/ekon/209_6_2/pdf/052-055.pf [in Ukrainian]. 7. Makarenko, I. O. (2005). Alhorytm antykryzovogo upravlinnia pidpryiemstvom [The Algoritm of the enterprise crisis management]. Aktualnye problem ekonomyky - Actual problems of economy,3,104-109 [in Ukrainian]. 8. Augustine N. R. (1995). Managing the Crisis You Tried to Prevent. Harvard Business Review, 73(6). p. 147-158. 9. Fronz, C. (2011). Strategic Management in Crisis Communication: A Multinational Approach. Hamburg, Diplomica Verlag GmbH, 175 p. 10. Taiichi Ohno, (1988). Toyota Production System: Beyond Large-Scale Production. CRC Press, 176 p. 11. Orlicky J. (1975). Material Requirements Planning: The New Way of Life in Production and Inventory Management. NewYork: McGrow-Hill, 292 p. 12. State Statistics Service of Ukraine, Statistical collection "Regions of Ukraine" Retrieved from: http://www.ukrstat.gov.ua/ 13. State Audit Office of Ukraine (2017) Audit report on the results of the state financial audit of PJSC "Lviv Locomotive Repair Plant". Retrieved from: http://dkrs.kmu.gov.ua/kru/doccatalog/ document?id=131706 